\title{
The Challenges of Teaching Indonesian History in The Teaching Factory Learning Model in Vocational High School
}

\author{
Riski Gustiar ${ }^{1}$, Kurniawati², Murni Winarsih3 \\ DOI: $10.35445 /$ alishlah.v13i2.692
}

\begin{tabular}{l}
\hline Article Info \\
\hline Keywords: \\
Teacher Challenges; \\
History learning; \\
Teaching Factory
\end{tabular}

Kata kunci:

Tantangan guru;

Pembelajaran sejarah; Teaching Factory

\begin{abstract}
This study aims to identify teachers' challenges in teaching Indonesian History at SMK using the Teaching Factory learning model. This study uses qualitative methods by taking research at SMKN 28 South Jakarta. The analysis used is the grounded theory approach of Strauss and Corbin. The results illustrate three interrelated things: the Teaching Factory concept, the implementation and challenges faced by Indonesian History subject teachers, and the teacher's efforts to face these challenges. Based on the research results, it shows that the challenge faced by the teacher is the compaction of Indonesian History material in SMK. The teacher must accommodate students who cannot participate in learning activities in class and the absence of teaching materials based on the Teaching Factory. Efforts to answer these challenges based on the research results in the field can be overcome by; adjusting Indonesian History material in vocational schools, providing teaching materials that are easy to understand for students to learn independently, and making learning innovations in the skills process (KI-4).
\end{abstract}

\begin{abstract}
Abstrak
Penelitian ini bertujuan untuk mengidentifikasi tantangan yang ditemui guru dalam mengajar Sejarah Indonesia di SMK yang menggunakan model pembelajaran Teaching Factory. Penelitian ini menggunakan metode kualitatif dengan mengambil penelitian di SMKN 28 Jakarta Selatan. Analisis yang digunakan menggunakan pendekatan grounded theory Strauss and Corbin. Hasil penelitian menggambarkan tiga hal yang saling berkaitan, yakni konsep Teaching Factory, implementasi dan tantangan yang dihadapi guru mata pelajaran Sejarah Indonesia, dan upaya guru untuk menghadapi tantangan tersebut. Dari hasil penelitian diketahui bahwa tantangan yang ditemui guru adalah pemadatan materi Sejarah Indonesia di SMK, guru harus mengakomodir siswa yang tidak bisa mengikuti kegiatan pembelajaran di kelas, dan tidak adanya bahan ajar yang berbasis pada Teaching Factory. Upaya untuk menjawab tantangan tersebut yaitu dengan; melakukan penyesuaian materi Sejarah Indonesia di SMK, memberikan bahan ajar yang mudah dipahami oleh siswa untuk belajar secara mandiri, dan melakukan inovasi pembelajaran pada proses keterampilan (KI-4).
\end{abstract}

${ }^{1}$ Universitas Negeri Jakarta, Indonesia

Email: ustiar_riski@yahoo.comUniversitas Negeri Jakarta

2 Universitas Negeri Jakarta, Indonesia

Email: kurniawati@gmail.com

3 Universitas Negeri Jakarta, Indonesia

Email: Winarsih@gmail.com 


\section{INTRODUCTION}

The world of education has changed a lot from an integrated learning process to digitalization. However, some schools are experiencing challenges and readiness to face the flow of globalization. As a result, many educational institutions are still not ready to face the industrial revolution 4.0 with facilities and infrastructure. Even teachers have limited technology and technology in mastering computerization and the internet (Putra et al., 2020). Vocational High School is an academic unit within the scope of Vocational Secondary Education whose educational program focuses more on developing students' abilities to carry out certain types of work. This is in line with the concept that underlies the holding of vocational education, namely preparing middlelevel technicians to work in industry and filling new job opportunities that are open in line with the development of the industrial world (Hasbullah, 2005).

Vocational Secondary Education is secondary education that prioritizes students' abilities to carry out certain types of work. At the secondary education level, Vocational High Schools (SMK) and Madrasah Aliyah Vocational Schools (MAK) are schools organized by the government to prepare skilled students and develop students' professional attitudes in specific fields (Peraturan Pemerintah Nomor 29 Tahun 1990 Tentang Pendidikan Menengah., 1990). In addition, vocational education institutions also provide experience, both affective, cognitive, and psychomotor, to prepare students to enter the world of work so that students can work well and participate in the development of the country's economic sector. Based on the research results Yusran (2016), the proportion of the number of SMK 70\%, SMA 30\% in this country seems suitable if associated with continuing higher education. The consequence is that the world of work that will accommodate SMK graduates must be ready, although SMK graduates still need to be trained to enter.

One of the government's steps to prepare students to have competency skills that can compete globally is implementing the Teaching Factory learning model in Vocational High Schools (SMK). The Teaching Factory learning model is one of the industry-based learning models. The implementation of this learning model fully integrates learning and work activities, no longer separating the delivery of theory and practice, according to the results of research Santosa (Renita, Purnomo, Widiyanti dan Dika, 2020). The government implements a teaching factory as one of the efforts made to realize vocational schools that can produce entrepreneurial graduates who are ready to work, intelligent, competitive, have a national identity, and develop local advantages and compete in the global market. Teaching factory is a learning approach that effectively improves graduates' competence (Putra \& Syafrudin, 2020). Teaching factory learning aims to realize that teaching students should be more than just what is contained in books. Students practice soft skills in learning, learn to work in teams, practice interpersonal communication skills, and gain hands-on experience and work practice to enter the world of work. Teaching factory learning teaches students to find problems, build prototypes, make business proposals, and present their solutions (Nurtanto et al., 2017).

Based on the research results of Pramudyo dan Walidin (Renita, Purnomo, Widiyanti dan Dika, 2020), an increase in the quality of human resources to adapt to the development of an increasingly global era. Many believe that in improving human resources, one of the things that must be addressed is improving the quality of education. Efforts to develop human resources must be programmed by implementing learning programs that increasingly adapt to advances in science and technology. The resulting products are genuinely qualified and competent and can compete in the business or industrial world. One of the schools that implement the Teaching Factory learning model in Indonesia is SMKN 28 Jakarta.

The research by Rohmah et al. (2019) states that students will practice not only skills in learning through teaching factories. Besides, students also learn to work in groups which, will train students to communicate with others, gaining real experience, and practice doing work to prepare themselves when entering the world of work. In line with this, Chryssolouris, Mavrikios, Mourtzis 
emphasized that the Teaching Factory learning model is carried out by productive (vocational) subjects and adaptive and normative (general) subjects. This is because to produce competent students in their fields, of course, all parties must support them, not only from productive subjects but also from adaptive and normative subjects. For schools that implement the Teaching Factory learning model, of course, experiencing changes in learning. The implementation of the Teaching Factory learning model affects all aspects of learning activities, among others, learning modules, Learning Implementation Plans (RPP), and other matters related to learning administration. From the change in the learning model from the conventional one to the Teaching Factory learning model, researchers see that there are problems for schools that implement this Teaching Factory learning model.

Apart from the research results above, according to (M, 2019) the six-step teaching factory model is a research model of learning using the Research and Development method. This model aims to improve the productive competence of vocational students. The six steps of this model cycle are receiving the ordering provider, analyzing the order, stating readiness to work on the order, working on the order, performing quality control, and submitting the order. The model is carried out in a time block of six weeks in the fourth semester, six weeks in the fifth semester, and a competency test. The results showed that this model was effective in increasing students' productive competence. Based on this research, the originality of this research is from the history subject matter applied in SMK with different methods and models. This is by research (Renita, Purnomo, Widiyanti dan Dika, 2020) that the teaching factory that has been implemented in Malang City is quite good. However, it is still not optimal as a whole, so it is necessary to improve and increase the cooperation that has been carried out to produce competent students in their fields.

\section{METHODS}

This study uses a qualitative method using the grounded theory approach of Strauss and Corbin. This method is adapted to a systematic procedure for developing grounded theory (Sugiyono, 2013), arranged inductively on a phenomenon, developing an appropriate theory, and explaining the field under study. In its application, after collecting data, it is then detailed in the data analysis process through the data reduction process to focus data analysis on the central phenomenon being studied. The data analysis process is carried out by compiling data from observations and interviews with teachers, curriculum representatives, and several students regarding Teaching Factory-based Indonesian History learning in schools. The results of the data analysis made by the researcher are then concluded, and the synthesis will be written using easy-to-understand principles. The coding of the data retrieval results uses a way of classifying based on the themes found in the learning phenomenon at the school where the research is located. From this, the researcher will look at the themes in a separate history learning category. The first is regarding the concept of learning. The second is the implementation. The third is the challenges encountered in learning. This classification is based on the sub-focus of the research to be studied, then translated into categories used from the coding process. This research applies the triangulation technique with examination from other sources. Triangulation with the source in question tests the credibility of the data carried out by examining the data obtained through several sources (Sugiyono, 2008).

\section{FINDINGS AND DISCUSSION}

\section{Challenges of the Teaching Factory Learning Model in Vocational High Schools}

The research results were excavated through interviews at SMKN 28 South Jakarta that the learning development strategy for the teaching factory model at SMKN 28 Jakarta is based on internal factors (IFE) and external factors (EFE). The strategy given is aggressive, so the SO strategy is a strategy that is considered a high priority and urgent to be implemented. The strategy is to increase the variety of innovation according to the creativity of the students of SMKN 28 Jakarta to expand marketing targets in the Jakarta area. In addition, based on the results of interviews at SMKN 
28 Jakarta, supporting the Teaching Factory learning model for history teachers, the government also provides opportunities for them to hold exhibitions about historical museums in the international world to introduce their historical sites with affordable financing. Vocational students also urge the media to help promote products through online media or electronic media.

Based on the research above under the production Siswanto (2010), the teaching factory concept is a form of development from a vocational school to production activities. Teaching factory learning is a learning concept in production or service-based vocational schools that refer to standards and procedures that apply in the industry and is carried out in an atmosphere like what happens in the industry, such as the characteristics of vocational schools mentioned by Sofyan (Tentang Struktur Kurikulum Pendidikan Menengah Kejuruan, 2017) among them; (1) prepare students to enter the workforce; (2) based on the needs of the "demand-market-driven" world of work; (3) mastery of competencies required by the world of work; (4) student success in "hands-on" or work performance; (5) close relationship with the world of work; (6) responsive and anticipatory to technological advances; (7) learning by doing and hands-on experience; (8) requires higher investment and operational costs than general education.

In the Ministry of Religion of the Republic of Indonesia Curriculum (Putra \& Idawati, 2017), UU no. 20 of 2003 concerning the National Education System stated that national education functions are to develop capabilities and shape the character and civilization of a dignified nation in the context of the intellectual life of the nation. It aims to develop students' potential to become human beings who believe and fear God Almighty, have a noble character, healthy, knowledgeable, capable, creative, independent, and become democratic and responsible citizens. To achieve this goal, one of the fields of study that students must study in madrasas is Islamic Religious Education, intended to shape students into human beings who believe and fear God Almighty and have noble character.

The teaching factory learning paradigm aims to integrate educational, research, and innovation activities into industrial and academic activities through a curriculum, teaching/training approach. Teaching factory learning is expected to produce graduates who are in line with the needs of the industrial world. In addition, the teaching factory also integrates the learning process, which aims to produce products or services worth selling to instill an entrepreneurial spirit for students. This is under the results of Hidayat's research ( $\mathrm{F}$ et al., 2015). In this regard, by paying attention to various concepts and learning theories, a learning model called the 6-step Teaching Factory learning model (TF-6M Model) was developed. With the application of the TF-6M learning model, the atmosphere of the learning process is designed like an authentic industrial atmosphere. Through a model like this, it is hoped that students can understand more about the industry. Students more easily explore subject matter because they can get to know the lessons delivered by the teacher (Hidayat, 2010). The percentage of time that students can do hands-on practice will be much higher. Learning from experience is expected to be more meaningful and optimal in developing students' potential, rather than explaining more theory in class and doing a little practice by the expertise program taken in vocational high schools. The industrial atmosphere created in the TF-6M model is expected to provide more achievement motivation to students. Teaching factory learning aims to realize that teaching students should be more than just what is contained in books. Students practice soft skills in learning, learn to work in teams, practice interpersonal communication skills, and gain hands-on experience and work practice to enter the world of work. Teaching factory learning teaches students to find problems, build prototypes, make business proposals, and present their solutions. Rahmad's research results (Asriati et al., 2019) mention that at least two alternative vocational education models can be offered to integrate aspects of hard skills and soft skills comprehensively. (a) Learning aspects of soft skills, vocational basics, and entrepreneurship are carried out in schools, (b) Learning aspects of hard skills is carried out in the industry. 
According to Triatmoko (2017), Vocational High Schools still find it challenging to implement production-based education, so the term "teaching factory" appears, which requires schools to have a place for students to carry out practical learning designed in such a way as to resemble employment. Schools that apply the teaching factory learning model thoroughly combine learning and work to no longer separate the delivery of theoretical material and the place of production material. The basic principles of teaching factory in SMK in its implementation include; (a) the integration of work experience into the SMK curriculum, (b) all equipment and materials, as well as educational actors, are arranged and designed to carry out the production process to produce products, (c) there is a combination of production-based learning and competency learning, (d) ) in production-based learning, vocational students must be directly involved in the production process, so that their competence is built.

The Teaching Factory learning model has several types of models. The implementation of Teaching Factory according to the guidelines of the PMK Directorate is divided into four models, namely; (a) Experienced Based Training: Dual system in the form of fieldwork practice by way of learning in the workplace, (b) Competency-Based Training such as competency-based training. Assessment of students is designed to ensure that students have achieved the required competency values, (c) Production Based Education and Training: Production based learning approach. Students' competence is proven by making natural products needed by the industry, (d) Teaching Factory: The concept of synergizing learning between schools and industry. This model is the most widely used, wherein the learning model at school. Students focus on their skill competency activities combined with other subjects in school.

The implementation of the Teaching Factory learning model in schools has advantages and disadvantages. The advantages, among others, are that SMK graduates who implement this learning model are more prepared to respond to industry challenges. This is because students in learning at school focus on developing their competence according to their expertise in their field. In addition, another advantage is that this learning model uses references that have been prepared by the government. This is very useful because the government has mapped the human resource needs for future industrial needs. At the same time, the shortcomings in this learning model are that schools that implement the Teaching Factory learning model must have complete facilities and infrastructure according to their majors. Hence, they require significant capital in preparing the implementation of this learning model. In addition, this learning model makes other subjects, outside of productive subjects, no longer a concern of students. This is because they focus on subjects according to their area of expertise.

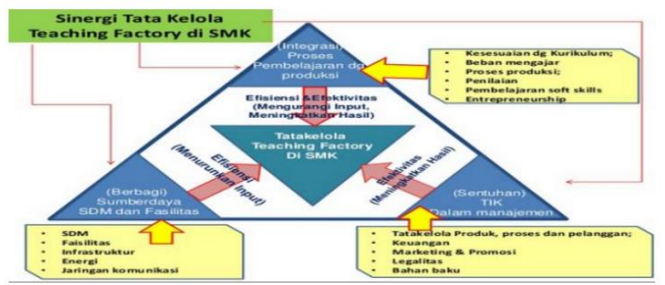

\section{Figure 1. Teaching Factory Learning (TEFA)}

\section{Learning Indonesian History in Vocational High Schools (SMK)}

Indonesian History subjects were taught from elementary school, then junior high school, where history subjects were integrated into social studies subjects and sociology and economics. Then at the SMA/MA level, history subjects are divided into two types, namely compulsory History (studying Indonesian History) and specialization history (studying world history). In contrast to the SMA/MA level, subjects in SMK/MAK only study Indonesian History. The number of hours of Indonesian history subjects in SMK/MAK also experienced a shift when issuing the Director General of Education and Culture Regulation No. 07/D.D5/KK/2018 changed the curriculum structure of subjects in SMK. The number of Indonesian history subjects in SMK, which was initially taught two 
hours per week, from class X to class XII, was reduced to only three hours per week and only taught in class X.

Table 1. Curriculum Structure of Vocational High School/Madrasah Aliyah Vocational School

\begin{tabular}{|c|c|c|c|c|c|c|}
\hline \multirow{3}{*}{ Subjects } & \multicolumn{6}{|c|}{ Class } \\
\hline & \multicolumn{2}{|c|}{$\mathbf{X}$} & \multicolumn{2}{|c|}{$\mathbf{X I}$} & \multicolumn{2}{|c|}{ XII } \\
\hline & 1 & 2 & 1 & 2 & 1 & 2 \\
\hline A. National Content & 3 & 3 & 3 & 3 & 3 & 3 \\
\hline 1. Religion and manner education & 2 & 2 & 2 & 2 & 2 & 2 \\
\hline 2. Pancasila and civic education & 4 & 4 & 3 & 3 & 2 & 2 \\
\hline 3. Indonesian & 4 & 4 & 3 & 3 & 2 & 2 \\
\hline 4. Mathematics & 4 & 4 & 4 & 4 & 4 & 4 \\
\hline 5. Indonesian History & 3 & 3 & - & - & - & - \\
\hline 6. English and other Foreign Languages ${ }^{*}$ ) & 3 & 3 & 3 & 3 & 4 & 4 \\
\hline amount A & 19 & 19 & 15 & 15 & 15 & 15 \\
\hline
\end{tabular}

Condensation of the subject matter of Indonesian History starting from the Basic Concept of History material to the material for the Evaluation of the Life of the Indonesian Nation in the development of science and technology. These materials are taught only in class X SMK, compared to the SMA level, where the material is taught from class X to class XII. It shows a striking difference in the history learning curriculum between the SMK and SMA levels. This opinion is in line with that expressed by Charles Prosser (Nurtanto et al., 2017) that effective vocational education can only be provided where the training tasks are carried out by the same means, tools, machines as those prescribed in the workplace. Teaching factory learning or industrial activity-based learning. Teaching factory is a learning concept in an actual situation to bridge the competency gap between the knowledge provided by the school and the needs of the industry. Applying the teaching factory learning concept can be one of the learning innovations in schools to develop teacher and student competencies. It is reinforced by (Habiba et al., 2020) that the research results show (a) the teaching factory The formulation of the program has been well defined, which includes aspects of urgency, has clear goals and objectives, and measures of success (b) the teaching factory program has quite well designed, (c) the teaching factory has been appropriately implemented which includes learning, practical activities, marketing and promotion, management, industrial relations, monitoring and evaluation, (d) teaching factory program products that provide positive results in the form of creating an industrial culture that able to increase productive competence and foster student entrepreneurial spirit and produce products/services that have added value with quality that can be absorbed and accepted by the community.

\section{Challenges of History Teachers in Teaching Indonesian History Subjects Based on Teaching Factory}

Based on research at SMKN 28 Jakarta, teachers face several challenges in teaching Indonesian History subjects based on Teaching Factory in schools. The challenge is that they must adjust the teaching time, which is only a little, namely 3 hours per week, to teach Indonesian History material consisting of 13 Basic Competencies (KD). This is complicated for the teacher because the material is so dense that it is only taught in class X. It is different from high school, where the material is almost the same, but it is taught from class X to class XII. Another challenge is that teachers must accommodate students who cannot participate in classroom learning because they have to participate in productive subject practice activities. In the Teaching Factory learning model, the learning system used at SMKN 28 is that students have a picket schedule to do work related to their respective majors. SMKN 28 Jakarta, 2-4 students every day who can't take lessons in class. Therefore, the teacher must accommodate these students who cannot take part in learning in class. 
The next challenge is that the teacher must adapt the teaching materials or textbooks used in teaching Factory-based learning. This is because teachers still use conventional teaching materials or textbooks provided for SMK in general. After all, the government has not provided textbooks for schools that hold the Teaching Factory learning model. The difference between conventional teaching materials and teaching materials for the Teaching Factory-based learning model lies in the process of skill activities (KI -4). Suppose in conventional teaching materials, the skill process focuses on general assignments to students. In that case, teaching materials in Teaching Factory learning focus more on making products related to students' majors under the taught material. This is under the results of research (Friadi \& Efendi, 2020) the increase in learning outcomes produced in the cognitive aspects of $20.70 \%$, psychomotor aspects $18.32 .68 \%$, and affective aspects $20.11 \%$ in the application of practical learning techniques by adopting Product-Based Factory Learning model that is feasible to implement.

\section{Teachers' Efforts to Overcome Challenges}

The many challenges faced by Indonesian History subject teachers in Vocational High Schools who apply the Teaching Factory learning model require efforts that teachers must make to overcome these challenges. Efforts made by teachers to answer these challenges are teachers being actively involved in MGMP activities (Subject Teachers' Meetings) in their regions. This is to make adjustments to the condensed subject matter of Indonesian History. In the MGMP activity, the Indonesian History teachers agree on which material should be taught and which material should be abandoned. Several materials overlap, so the teacher must skip the material, but it does not reduce the essence of the material left behind.

The next thing that teachers can do to answer these challenges is to provide teaching materials in the form of power points or online articles that students can study when their productive subject practice activities have been completed. The teacher also gives time to discuss material that is not understood by students who cannot participate in-class learning activities. The teacher also repeats last week's material at the beginning of the lesson. Students who were unable to attend class the previous week could draw a common thread from every historical event in the material.

Related to the teaching materials or textbooks used, teachers continue to use conventional textbooks. However, by innovating and being creative, learning is under the mission expected by the government, namely, students mastering competencies by their majors. In learning, the teacher gives assignments in the form of products developed by students related to the material discussed. This shows that although the assignment is not in the textbook used, the teacher has tried to adapt to the Teaching Factory learning model. This is not a problem because the Indonesian History teacher is still by the Teaching Factory-based learning corridor. Because what the Indonesian History subject teacher did was included in the category of innovative learning and productive practices oriented to student management in learning to be in line with the needs of the industrial world (Yudisman, 2018).

\section{CONCLUSION}

Teaching Factory-based Indonesian History learning at SMKN 28 Jakarta has been going well. Because in its application, Indonesian History subject teachers have answered the challenges faced in Teaching Factory-based learning activities. The challenges faced by the teacher include the adjustment of Indonesian History material in Vocational Schools, which is condensed and only studied in class X, with an allocation of 3 hours of lessons per week. The teacher was finally able to answer the challenge by conducting discussions between Indonesian History subject teachers regarding which materials could not be given to students but did not reduce the essence of the material. In addition, teachers also face challenges to accommodate students who cannot participate in classroom learning because they have to participate in productive subject practice activities. In this case, the teacher can answer it by providing teaching materials in the form of power points or online articles that have high credibility by the material being taught. The last challenge is the 
absence of teaching materials that are by the characteristics of Teaching Factory-based learning so that teachers make learning innovations so that Indonesian History learning that occurs in schools can meet the standards of the Teaching Factory learning model. Further researchers should focus on innovation, and product diversification needs to be improved.

\section{REFERENCES}

Asriati, N., Sulistyarini, Ulfah, M., \& Purwaningsih, E. (2019). Pengembangan Model Pembelajaran Teaching Factory 6M Menghadapi Revolusi Industri Keempat di SMK Negeri 6 Pontianak. JURKAMI : Jurnal Pendidikan Ekonomi, 3(2), 70-86. https://doi.org/10.31932/jpe.v3i2.334

F, A., Amar, Hidayat, D., \& Suherman, A. (2015). Penerapan model pembelajaran teaching factory 6 langkah (model tf-6m) untuk meningkatkan motivasi berprestasi siswa di SMK. Journal of Mechanical Engineering Education, 2(2), 189-198.

Friadi, J., \& Efendi, R. (2020). Development of Product-Based Learning-Teaching Factory in the Disruption Era. International Journal of Advanced Science and Technology, 29(06), 18871898.

Habiba, P. G. S., Sujanto, B., \& Karnati, N. (2020). Evaluation of Implementation of Teaching Factory Programs in State Vocational School, South Jakarta. International Journal Of Education And Research, 8(1), 157-164. http://www.ijern.com/journal/2020/January2020/13.pdf

Hasbullah. (2005). Implementasi Pabrik Pengajaran (Teaching Factory) Untuk Meningkatkan Kompetensi Siswa Smk. Jurnal Seminar Internatsional FPTK UPI, 395-402.

Tentang Struktur Kurikulum Pendidikan Menengah Kejuruan., (2017).

M, D. H. (2019). Model Pembelajaran Teaching Factory Untuk Meningkatkan Kompetensi Siswa Dalam Mata Pelajaran Produktif. 229.

Nurtanto, M., Ramdani, S. D., \& Nurhaji, S. (2017). Pengembangan Model Teaching Factory Di Sekolah Kejuruan. Prosiding Seminar Nasional Pendidikan, 467-483. http://jurnal.untirta.ac.id/index.php/psnp/article/view/447-454

Peraturan Pemerintah Nomor 29 Tahun 1990 Tentang Pendidikan Menengah., (1990).

Putra, P., \& Idawati. (2017). Telaah Kurikulum dalam Mata Pelajaran Al-Qur'an Hadist di Madrasah Ibtidaiyah. JIP: Jurnal Ilmiah PGMI, 3(2), 108-119. http://jurnal.radenfatah.ac.id/index.php/jip

Putra, P., Mizani, H., Basir, A., Muflihin, A., \& Aslan. (2020). The relevancy on education release Revolution 4.0 in Islamic basic education perspective in Indonesia (an analysis study of Paulo Freire's thought). Test Engineering and Management, 83(10256), 10256-10263.

Putra, P., \& Syafrudin, S. (2020). Scramble Learning Model to Improve the Ability Reading the Quran in Elementary School/Model Pembelajaran Scramble untuk Meningkatkan Kemampuan Membaca Al-Quran pada Mata Pelajaran Al-Quran Hadits di Madrasah Ibtidaiyah. Journal ALMUDARRIS, 3(1), 26. https://doi.org/10.32478/al-mudarris.v3i1.332

Renita, Purnomo, Widiyanti dan Dika, W. J. (2020). Studi Tentang Pelaksanaan Teaching Factory Smk Di Kota Malang ( Studi Multi Kasus ). Jurnal Pendidikan Teknik Mesin Volume, 7 (November), 150-160.

Rohmah, W., Efita Sari, D., \& Wulansari, A. (2019). Pembelajaran Berbasis Teaching Factory Di Smk Negeri 2 Surakarta. Jurnal Pendidikan Ilmu Sosial, 29(2), $78-85$. https://doi.org/10.23917/jpis.v29i2.9171

Siswanto, H. (2010). Pendidikam Kesehatan Anak Isia Dini. Pustaka Rihana.

Sugiyono. (2008). Metode Penelitian Pendidikan; Pendekatan Kuantitatif, Kualitatif dan R\&D. Alfabeta CV.

Sugiyono. (2013). Metode Penelitian Pendidikan Pendekatan Kuantitatif, Kualitatif dan R\&D. Alfabeta.

Yusran. (2016). Masyarakat ekonomi asean (MEA) antara harapan dan tantangan dari sudut pandang pendidikan. Prosiding Seminar Nasional Biotik, 53(1), 59-65. http://dx.doi.org/10.1016/j.encep.2012.03.001 